\title{
Assent for children's participation in research is incoherent and wrong
}

\author{
Paul Baines
}

Centre for Professional Ethics, Keele University, Staffordshire, UK

\section{Correspondence to Dr Paul Baines, Paediatric Intensive Care Unit, Alder Hey Children's Hospital, Eaton Road, Liverpool L12 2AP, UK; pbb@liv.ac.uk}

Accepted 28 April 2011 Published Online First 19 July 2011
This paper is freely available online under the BMJ Journals unlocked scheme, see http:// adc.bmj.com/info/unlocked.dtl

\begin{abstract}
When children are considered for participation in research, British and international guidelines suggest that they should provide assent in addition to their parents' consent. However, examination of these guidelines shows there is confusion regarding the concept of assent. Furthermore, the need for assent may cause problems. The guidelines should be revised: the parents of incompetent children should consent for them and competent children should consent on their own behalf.
\end{abstract}

\section{INTRODUCTION}

Authoritative international guidance requires that children provide assent for participation in research in addition to their parent's consent. However, as the concept of assent is not clear and may even be harmful, the guidelines need to be reformulated.

Generally, competent adults consent to participate in research. The situation is different for children: the child's parents consent on the child's behalf, and research ethics guidelines also require the child's assent (table 1). Despite this consensus, the guidelines do not give a clear definition of assent, nor do they provide any good reasons why assent is valuable. Also, on examination, assent lacks meaning and so should be removed from existing guidelines. In its place we should recognise that competent children should consent and that decisions should be made for incompetent children by their parents.

\section{CHOICES FOR CHILDREN}

Research guidelines emphasise that "Participation by competent individuals as subjects in medical research must be voluntary". ${ }^{1}$ The equivalent for incompetent children is seen to be consent from a parent and assent by the child (table 1).

Young children are not competent to make the more significant decisions in their lives. Choices are made for incompetent children by their parents, or their parents confirm choices that incompetent children make, or adults guide the decision-making of incompetent children in order that the child comes to the right decision. At times children's decisions are over-ruled by their parents. All of these (and other) strategies are used by parents to make decisions for their children. ${ }^{2}$ Parents make these choices, often in the interests of their child, but they also consider the interests of others in the family. The child's participation (if they participate at all) in the choices that are made is often limited to expressing their view. The child may be involved in deliberation, but in

\section{What is already known on this topic}

Research guidelines require a child's assent as well as their parents' consent for the child to take part in research.

\section{What this study adds}

-What assent means is not clearly defined and, furthermore, different guidelines give contrasting definitions; asking for assent may cause problems.

- An approach which relies on the consent of competent children and parental consent for incompetent children is to be preferred.

- The guidelines should be revised.

the end the choice is made by the parents. And even if the parents allow the child to choose, the parents carry responsibility for the decision. The parents may have regard to their child's views, but these views are only one factor in the parents' decision.

However, in some cases, paradigmatically when children's participation in research is discussed, the recommendations are that children should assent (listed in table 1). What assent means is not clear, nor do the documents clearly define assent.

\section{OFFICIAL GUIDANCE REGARDING CHILDREN'S PARTICIPATION IN RESEARCH}

The first international consensus guidance on research (the Nuremberg Code) excluded children altogether, or this was at least one interpretation given the requirement that "the voluntary consent of the human subject is absolutely essential". ${ }^{3}$ However, this requirement protects children from the risks of research, but also prevents them from reaping the rewards of research. Since then the guidance has evolved. The latest amendments to the Declaration of Helsinki (verified in 2008) state: "When a potential research subject who is deemed incompetent is able to give assent to decisions about participation in research, the physician must seek that assent in addition to the consent of the legally authorized representative. The potential subject's dissent should be respected". 1

There is widespread agreement that assent is required for the participation of children in research (table 1). However, what assent means is not clear. Some guidelines attempt a definition (table 2). If we accept that children's enthusiasm 
Table 1 Requirement for assent in international guidelines

\begin{tabular}{|c|c|c|}
\hline Research guideline & Text & Jurisdiction \\
\hline $\begin{array}{l}\text { The Declaration of } \\
\text { Helsinki }^{1}\end{array}$ & $\begin{array}{l}\text { "... the physician must seek that } \\
\text { assent..." }\end{array}$ & International \\
\hline $\begin{array}{l}\text { Council for International } \\
\text { Organizations of } \\
\text { Medical Sciences }^{11}\end{array}$ & $\begin{array}{l}\text { "Assent of the child. The willing } \\
\text { cooperation of the child should be } \\
\text { sought..." }\end{array}$ & International \\
\hline $\begin{array}{l}\text { Code of Federal } \\
\text { Regulations (Part } 50)^{4}\end{array}$ & $\begin{array}{l}\text { “... the IRB must determine that } \\
\text { adequate provisions are made } \\
\text { for soliciting the assent of the } \\
\text { children..." }\end{array}$ & USA \\
\hline $\begin{array}{l}\text { American Academy of } \\
\text { Pediatrics }^{9}\end{array}$ & $\begin{array}{l}\text { "Assent should be obtained from } \\
\text { children who are competent to } \\
\text { understand" }\end{array}$ & USA \\
\hline $\begin{array}{l}\text { Confederation of } \\
\text { European Specialists in } \\
\text { Paediatrics }^{6}\end{array}$ & $\begin{array}{l}\text { "All children, even those not judged } \\
\text { as competent, have a right to } \\
\text { receive information given in a way } \\
\text { that they can understand and give } \\
\text { their assent or dissent" }\end{array}$ & European \\
\hline $\begin{array}{l}\text { The Royal Australasian } \\
\text { College of Physicians }{ }^{12}\end{array}$ & $\begin{array}{l}\text { "Agreement to participate should } \\
\text { usually be sought... from those } \\
\text { children who are capable of } \\
\text { understanding decisions and their } \\
\text { consequences" }\end{array}$ & $\begin{array}{l}\text { Australia and } \\
\text { New Zealand }\end{array}$ \\
\hline $\begin{array}{l}\text { Medical Research } \\
\text { Council }^{13}\end{array}$ & $\begin{array}{l}\text { If the child is able to give assent } \\
\text { to decisions about participation } \\
\text { in research, the investigator must } \\
\text { obtain that assent..." }\end{array}$ & UK \\
\hline
\end{tabular}

IRB, institutional review board or ethics committee.

for research runs the gamut from expressed assent, through silent assent, through indifference and then from passive dissent to active dissent, there are clear differences in the guidelines. Some emphasise expressed (or positive) assent, for example, "affirmative agreement", ${ }^{4}$ while some indicate a lack of dissent, for example "acquiescence". ${ }^{5}$ Another problem with the definitions is that they may conflate ethical and legal concepts, suggesting that children who are not legally competent to consent should assent. ${ }^{6} \mathrm{~A}$ third problem is that the definitions themselves need further clarification. For example what does 'acquiescence' mean? For all of these reasons, assent is not given a clear meaning in the guidance.

Another way to understand what we mean by assent is to describe the limits of assent. The upper limit to assent is the ability to consent. Children lacking one or more of the requisite skills for competence to consent will assent. What is needed for consent has been well described. ${ }^{7}{ }^{8}$ If assent has a place, then those who lack these abilities should assent.

If assent has a specific meaning, then it should have a lower limit too. It would certainly seem wrong to fail to pay attention to the expressed wishes of a 12 -year-old child, but there is less sense in assent from a child with less developed reasoning and it is impossible to involve a preverbal child in a reasoned assent.

Consider the lower age limit that is proposed for assent: this may clarify it. American guidance suggests that school age children should assent, although this is left to the discretion of the institutional review board. ${ }^{4}$ Other official American guidance suggests children over the age of 7 should assent. ${ }^{9}$ Wendler and Shah ${ }^{10}$ argued that the "autonomy rationale" and the requirement for altruism set the age for assent at 14 years, which is towards the age at which British courts recognise that children are able to consent to treatment in their own right. ${ }^{7}$ Again, the notion of assent is confused.

This brief summary demonstrates that the guidance is inconsistent and that the concept of assent is neither understood nor
Table 2 Definition of assent in research guidelines

\begin{tabular}{lll}
\hline Research guideline & Text & Jurisdiction \\
\hline Code of Federal & "Assent means a child's & USA \\
Regulations & affirmative agreement, to & \\
& participate in research. Mere & \\
& failure to object should not, \\
& absent affirmative agreement, \\
& be construed as consent."
\end{tabular}

American Academy of "... active agreement by a minor, Pediatrics $^{9} \quad$ not qualified to give consent, to participate in a research study. This generally applies to children who have reached an intellectual age of 7 years or greater."

Council for International "Such knowing agreement, Organizations of Medical Sciences ${ }^{11}$ Confederation of European Specialists in Paediatrics $^{6}$ sometimes referred to as assent..."

"Informed assent means a child's agreement for medical procedures in circumstances where he or she is not legally authorised or has insufficient understanding to be competent to give full consent."

Royal College of Paediatrics and Child Health ${ }^{5}$

Medical Research Council $^{13}$

“... 'assent' refers to acquiescence..."

“... affirmative agreement to participate. Failure to object should not be construed as assent" but later on "Does the child actively object?" and if no, "research may proceed"*

The Royal Australasian

"... the term assent for concurrence or agreement, without the formal and legal expectations of informed consent."

clearly defined. It does not demonstrate that the idea of assent is wrong. One response to these criticisms is to recognise that there is no clear understanding of assent, but to argue that it is a convenient fiction and does no harm. However, the demand for assent may cause problems.

\section{PROBLEMS WITH ASSENT}

First, a practical problem arises if the parent and child give incompatible responses when asked to consent and assent. The research will either continue or be withheld and one side will be over-ruled. If the child can be over-ruled, what is the purpose of assent? It seems meaningless. Alternatively, if the assent is respected (the children are given a separate veto or right to permit research) and the parents are over-ruled, then the parents cannot be giving consent at all (in the way that consent is usually understood). This demonstrates confusion in relation to both consent and assent: if both consent and assent are required, then consent is not consent (as it is generally taken to be the authority to proceed with a course of action). And if consent is the authority to proceed, then assent has no role.

Second, assent is emphasised in research, but is largely ignored in medical treatment for children. In adults, consent underlies our approach to participation in both research and treatment (justified by an appeal to respect for autonomy). If a child's medical treatment may proceed with consent from the 
parents but the child's participation in research requires both consent from the parents and the assent of the child, then the justification for treatment and research are clearly different. This requires clarification.

Third, the requirement for assent may cause other moral problems. In the above example, if parents do choose for their children (and ignore the child's views) or if a child's assent contains a veto over the parents' consent, then we may introduce tensions into the decision-making within a family, which itself may harm relationships with children.

A further problem is that the researcher may allow competent children to assent, while asking their parents to consent. The harm here is that if children are competent, their decisions should be respected: they should consent. Assent may mean that the researcher does not consider whether the children should themselves consent and so may fail to respect the autonomy of a competent child.

As well as this, if we maintain the fiction of children's assent, then we may not properly distinguish research on adults from research on children. In respecting an adult's autonomy an adult may enter trials that carry risks and consciously accept those risks because of advantages to others (perhaps the community of those who have the disease), or if they have an inherited disease, benefits for their children or grandchildren. Children's participation in research is based on an assessment of the child's interests and they should not be exposed to the risks that adults may choose to accept. This difference may be concealed if assent is taken to be equivalent to consent.

For all of these reasons, assent is not just a convenient fiction, but can cause harm.

\section{CONCLUSIONS}

We should acknowledge that the concept of assent is ill thought-out, confused and harmful. We should accept that competent children can and should consent to take part in research. We should allow the parents of incompetent children to consent for them. Parents of incompetent children should be encouraged to discuss participation in research with their children for a wide variety of reasons: this approach is most likely to get closer to the child's interests and will facilitate the development of the child's autonomy, and more discussion of research broadens knowledge of research. We should recognise the importance of dissent, although what is meant by dissent needs further examination and clarification. For example, if a baby cries when participating in research (as they may do when their nappy is changed) is this dissent? Obviously it would be wrong for a baby to suffer prolonged or intractable distress.

The bodies that generate guidelines for research involving children should reconsider their guidelines.

Acknowledgements $\mathrm{PB}$ is grateful to Dr Dawson (of Keele University) for his constructive criticisms. A preliminary version of this work was presented at the 10th World Congress of Bioethics, 28-31 July 2010 in Singapore.

Funding PB is funded by the Wellcome Trust (Grant 087470).

Competing interests None.

Provenance and peer review Not commissioned; externally peer reviewed.

\section{REFERENCES}

1. WMA. WMA Declaration of Helsinki - Ethical Principles for Medical Research Involving Human Subjects. 2008. http://www.wma.net/ en/30publications/10policies/b3/index.html (accessed 4 Aug 2010).

2. Rowntree Foundation. Children's Involvement in Family Decision-Making. 2005. http://www.jrf.org.uk/sites/files/jrf/0365.pdf (accessed 9 Aug 2010).

3. Trials of War Criminals Before the Nuernberg Military Tribunals, Under Control Council Law No. 10 October 1946 - April 1949 (the Green Series) volume II p 181. http:// www.loc.gov/rr/frd/Military Law/NTs war-criminals.html (accessed 6 Aug 2010).

4. Protection of human subjects - research involving children: proposed rule. Fed Regist 1978;43:31785-94.

5. McIntosh N, Bates P, Brykczynska G, et al. Guidelines for the ethical conduct of medical research involving children. Royal College of Paediatrics, Child Health: Ethics Advisory Committee. Arch Dis Child 2000;82:177-82.

6. De Lourdes Levy M, Larcher V, Kurz R, ; Ethics Working Group of the Confederation of European Specialists in Paediatrics (CESP). Informed consent/ assent in children. Statement of the Ethics Working Group of the Confederation of European Specialists in Paediatrics (CESP). Eur J Pediatr 2003;162:629-33.

7. Gillick v West Norfolk and Wisbech Area Health Authority (1985) 3 All ER 402, HL.

8. Buchanan AE, Brock DW. Deciding for Others: The Ethics of Surrogate Decision Making. Cambridge University Press 1990.

9. Guidelines for the ethical conduct of studies to evaluate drugs in pediatric populations. Committee on Drugs, American Academy of Pediatrics. Pediatrics 1995;95:286-94. http://pediatrics.aappublications.org/cgi/reprint/95/2/286 (accessed 19 May 2011)

10. Wendler D, Shah S. Should children decide whether they are enrolled in nonbeneficial research? Am J Bioeth 2003;3:1-7.

11. Council for International Organizations of Medical Sciences. International Ethical Guidelines for Biomedical Research Involving Human Subjects: Commentary on Guideline 14. http://www.recerca.uab.es/ceeah/docs/CIOMS.pdf laccessed 19 May 2011).

12. The Royal Australasian College of Physicians. Paediatrics \& Child Health. Sydney: The Royal Australasian College of Physicians, 2008. Ethics of Research in Children. http://www.racp.edu.au/page/policy-and-advocacy/paediatrics-and-child-health (accessed 19 May 2011)

13. Medical Research Council. Medical Research Involving Children. London: MRC, 2004. http://www.mrc.ac.uk/Utilities/Documentrecord/index. htm?d=MRC002430 (accessed 9 August 2010). 